The Journal of Animal \& Plant Sciences, 30(6): 2020, Page: 1633-1641

ISSN (print): 1018-7081; ISSN (online): 2309-8694

\title{
STRATEGIC EXPLORATION OF POTENTIAL GROWTH FOR THE SELECTION OF NICHES FOR OXALIS SPP.
}

\author{
A. Rashid ${ }^{1}$, T. A. Cheema ${ }^{1}$, A. U. H. Khan ${ }^{2}$, F. Zahid ${ }^{1}$, Z. Bashir ${ }^{1}$, S. A. Mirza ${ }^{1}$ and S. Ali3* \\ ${ }^{1}$ Department of Botany, GC University Lahore, Pakistan \\ ${ }^{2}$ Sustainable Development Study Centre (SDSC), GC University Lahore, Pakistan \\ ${ }^{3}$ Institute of Industrial Biotechnology (IIB), GC University Lahore, Pakistan \\ *Corresponding author's email: prof.dr.sikanderali@gcu.edu.pk
}

\begin{abstract}
The present study was an endeavor to investigate the growth strategies of Oxalis corniculata L., O. corymbosa DC. and O. pes-caprae L. The distribution and seasonal pattern of growth of Oxalis spp. was followed by regularly harvesting the species and measuring growth parameters on monthly basis at selected sites. It seemed that the growth pattern of the species allows them to select particular niches in the garden. The comparative analysis of life cycle showed that $O$. corniculata has the longest growing season and reproduce by seeds and vegetative propagules, whereas $O$. corymbosa and $O$. pes-caprae have short growing seasons and reproduce by vegetative propagules only. It appeared that $O$. corniculata is Competitive Ruderal (C-R) garden weed with occurrence on less disturbed areas and its growth strategies allow it to compete with other grasses in the same habitat. Oxalis corymbosa and O. pes-caprae are Stress-Tolerant Ruderals (S-R) as they are found at disturbed sites. Mode of vegetative reproduction of $O$. corymbosa is more efficient as compared to O. pes-caprae. O. pes-caprae have more specialized niches and spot bound mode of vegetative propagules that make it the most vulnerable in the gardens as compared to the other two species.
\end{abstract}

Key words: Oxalis corniculata, Oxalis corymbosa, Oxalis pes-caprae, Growth Strategies, Lahore, Pakistan.

https://doi.org/10.36899/JAPS.2020.6.0184

Published online August 03,2020

\section{INTRODUCTION}

The plant growth strategies are the groupings of similar or comparable chromosomal characteristics which recur widely among the species or populations (Evans, 1973; Causton and Venus, 1981; Tilman, 1988); these cause the species to exhibit similarities in ecology (Hunt, 2012). In Grime's C-S-R triangle, different species are located at specific points (Grime, 1979). These species are accommodating a definite percentage of each of the three strategies (Grime and Pierce, 2012). In the field of plant biology, the theory of Grime's C-S-R triangle is the application of universal adaptive strategy theory (UAST) (Grime, 2001). Throughout the life cycle of a plant, the universal three-way trade-off (C-S-R) produces adaptive strategies (Pierce et al., 2017) which facilitate the survival of genes through: $\mathrm{C}$, competitive, which is the survival of the individual using traits that make the most of resource attainment and control in consistently productive niches; $\mathrm{S}$, stress-tolerant, which is the individual survival through maintenance of metabolic performance in variable and unproductive niches; or R, ruderal, which is the rapid gene spread through speedy completion of the life-cycle and revival in niches where events are often harmful to the species (Grime et al., 2007). Each of the strategy thrives best in an exclusive amalgamation of either high or low intensities of stress and disturbance. These three strategies are extremes of evolutionary specialization (Pierce et al., 2013).

$O$. corniculata is a perennial and cosmopolitan garden weed (Sykes et al., 2009; Peng et al., 2007; Malik, 2012). It is capable of growing in habitats that sustain periods of drought as well (Kumar et al., 2012). The species is medicinally significant (Kathiriya et al., 2010; Jain 2010; Badwaik et al., 2011). The species also possess heavy metal tolerance (Mufti et al., 2015). In flora of Pakistan, Nasir (1971) designated O. corymbosa as an annual herb. It is commonly considered as weed for crops. According to Nasir (1971), O. pes-caprae is an invasive perennial herb having partially underground stem (Sala, 2007). It is always found in a group of five to six plants (Castro et al., 2006). O. pes-caprae is designated as a poisonous plant as it leads to death of livestock as a result of excessive grazing (Vila et al., 2006; Askari, 2010). O. corniculata (native) was grown with an alien Oxalis sp. (O. dilleniid) in manmade environment in Japan that showed higher adaptivity of $O$. corniculata to co-exist with alien species (Fukatsu, 2019). The growth strategies are predictable through general surveys of natural habitats, distribution patterns and abundance, growth and development by seasonal harvest, soil analysis of the preferred habitat and the reproductive potential of the species concerned in study site following the flora (Kashyap, 2015). The objective of 
the study was to investigate that why all the three species occupy particular niches in their habitats.

\section{MATERIALS AND METHODS}

Study area: Three species of Oxalis, i.e. O. corniculata, $O$. corymbosa and $O$. pes-caprae, were commonly found in the Botanic Garden lawns, GC University Lahore, lawns of Botany Department, GC University, Lahore, hills and drains in Jinnah Garden and suburban arable fields and forest lands of the park.

Reconnaissance survey for habitat: A survey was carried out from the month of October (2017) till September (2018). The selected study areas were visited three times for accessing their average monthly abundance.

Quadrat method for percentage cover: The study was carried out by quadrat method on the three selected plots on monthly basis (Stohlgren, 2007). The plots selected were marked and kept non-mowed for the period of study. Quadrat was placed around the plots every month to count the number of plants present within it for estimating the percentage cover.

Growth analysis by seasonal harvest: Plots of dense population of the plant species under study were selected and the productivity of species was determined (Mehmood et al, 2011). The lengths of the shoots and roots were measured separately. Similarly, the fresh and dry weights of species were measured.

Root analysis for reproductive potential: A general survey of garden was carried for the said duration to identify less disturbed sites where monthly harvest was to be carried out. Root parts (rhizomes) were collected and examined in pre-mature phase and after maturation (Shu, 2008).

Soil analysis of the preferred habitat: The soil of these species was collected to measure the percentage organic matter and moisture content. A gram of oven-dried soil was titrated against $0.5 \mathrm{M}$ ferrous ammonium sulfate solution to find molarity until the color of solution changes from violet-blue to green in a beaker. Percentage oxidizable organic carbon (w/w) was measured by molarity of the solution. The total organic carbon (\%) was estimated through percentage oxidizable organic carbon. Percentage organic matter and moisture content in soil was measured by following formulae (Burt et al., 2013):

Organic Matter $(\%)=1.728 \times$ Total organic carbon $(\%)$ Moisture $(\%)=$ Fresh weight $(\mathrm{g})-$ Dry weight $(\mathrm{g}) \times 100$ Fresh weight $(\mathrm{g})$

Statistical analysis: The data regarding lengths and weights of plant species were analyzed by one-way analysis of variance (ANOVA) using software (SPSS Version-20). The differences among the mean values for moisture and soil analysis were computed at a significance level of $\mathrm{p} \leq 0.05$ (Steel et al., 1996).

\section{RESULTS AND DISCUSSION}

Habitats of Oxalis spp.: Results showed that $O$. corniculata was prevalent in all the lawns which were regularly mowed (Fig. 1a). It was found in gardens everywhere along the sites of plots, plantations and along the roads as well as wild species. This species was also found in sub-urban areas of city as well which corroborates it as a cosmopolitan weed. However, it was not found along the drains and arable fields.

$O$. corymbosa was mainly distributed in waste lands or along sewage channels, mostly found near wet and moist places (Fig. 1b). It was usually found in specific areas where moisture was abundant in soil. It has not been observed in the mowed lawns and arable wastelands. This indicates that the requirement of moisture content for the occurrence of this species was comparatively higher than the other two species.

$O$. pes-caprae was present along the margins of arable fields (Fig. 1c). It was prevalent in fields where vegetables were cultivated. However, it was absent in the mowed lawns and alongside the drainage areas.

Percentage cover: The percentage cover of the three Oxalis spp. was compared to assess their distribution patterns (Fig. 2). O. corniculata was observed to be present almost around the year; however, its growth was suppressed during the extreme winters. This species was found to bear seeds, indicative of sexual reproduction in this plant. The plant normally shed seeds by the end of March and new plants emerged at the same time, being in full bloom from April to July, this species seemed to grow preferably in the garden soil. It exhibited excellent growth in areas where the climate was moderately warm and sunlight was easily available.

O. corymbosa was observed to be growing usually from December to April. The species reproduces vegetatively and was not observed to bear seeds. The plant was observed to grow in the month of December and was seen in full bloom in the months of January and February. The characteristic feature of this species was that it seemed to prefer to grow along drainage, or muddy areas, partially shaded, or sunlight was not available at all, owing to its requirement of higher moisture content.

$O$. pes-caprae spp. was observed to growing from January to April in full bloom in the months of January, February and March however, its growth was suppressed during extreme hot summer i.e. in the months of June and July. This plant preferred to grow along the margins of cultivated lands. It showed excellent growth in areas where the soil had moderate moisture level and 
in areas where sunlight was available. The preference of such habitat shows a correlation between the growth of this species with higher temperature, moderate rainfall and moderate humidity.

Growth analysis: Growth was assessed by measuring stem length variations of three Oxalis spp. (Fig. 3). O. corymbosa and $O$. pes-caprae suffered sudden decline in the upper shoot parts whereas the prevailing organs retained considerable biomass. Prevailing organs were larger in size and weight in O. pes-caprae as compared to $O$. corniculata. It seemed that the amount of biomass (weight) including above and below ground parts was significantly higher in the following order (Fig. 4):

$O$. pes-caprae $>O$. corymbosa $>O$. corniculata

Root analysis: Rhizomes of the three species were compared morphologically in pre-mature and maturation phase (Table 1). The result showed that $O$. pes-caprae and $O$. corymbosa's reproductive period is short whereas $O$. corniculata reproduce round the year. This was the reason that $O$. pes-caprae and $O$. corymbosa invest in producing biomass in prevailing organs.

Soil analysis: The percentage moisture content and organic matter was compared in three species (Fig. 5). The data shows that highest amount of organic matter is present in O. corniculata; whereas, the highest amount of moisture is present in O. corymbosa.

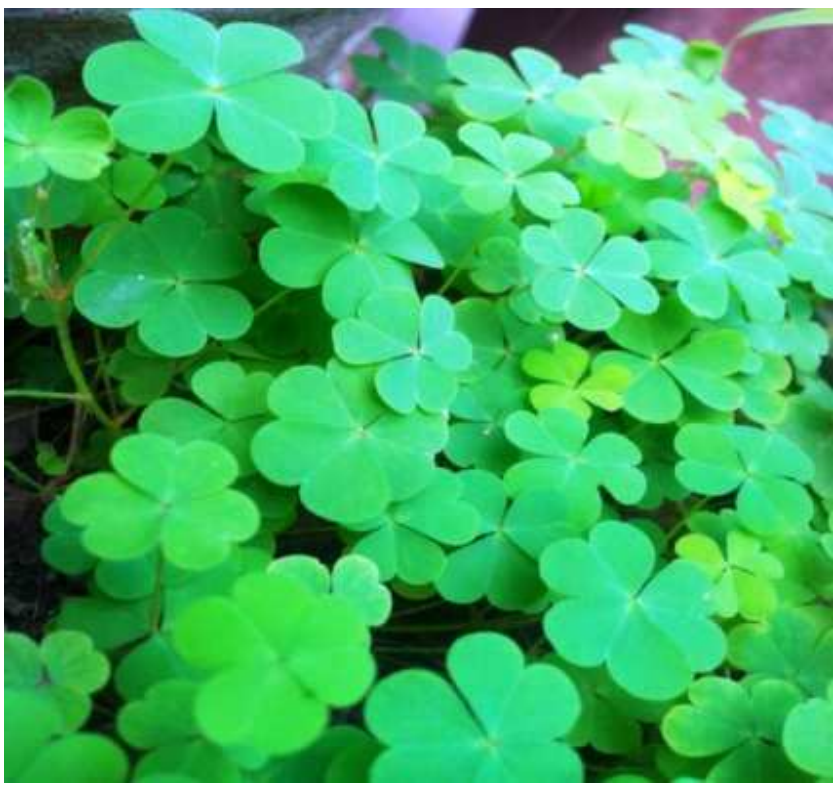

a. O. corniculata $\mathrm{L}$.
Grime's triangle for Oxalis spp.: The life cycles of three spp. were drawn in comparison to analyze their reproductive and dormant stages (Fig. 6). An attempt was made to place the species in the model designed by Grime (1977) in the present work (Fig. 7). In the present study, the data collected from natural populations clearly suggested that $O$. corniculata possessed all characteristics of the competitor which exhibit high productivity and experience very high intensities of disturbance. $O$. corniculata typically grew in grasslands, woodlands and disturbed sites and did well in both sunlight and shade.

The characteristic feature observed about $O$. corymbosa was that it only grew near drainage or ponds or muddy areas due to requirement of higher moisture content by plant. It showed excellent growth where area was partially shaded with sunlight or not available. According to Tsai (2010), O. corymbosa is an exotic species. Hence, the species was found in less disturbed lands.

$O$. corymbosa and $O$. pes-caprae seemed to be more stress tolerant than being competitive. However, the stress-tolerant condition was more prominent in $O$. pescaprae; while $O$. corymbosa was more competitive due to presence of perinnating organs underground that stored photosynthetic material when its shoots were disappeared.

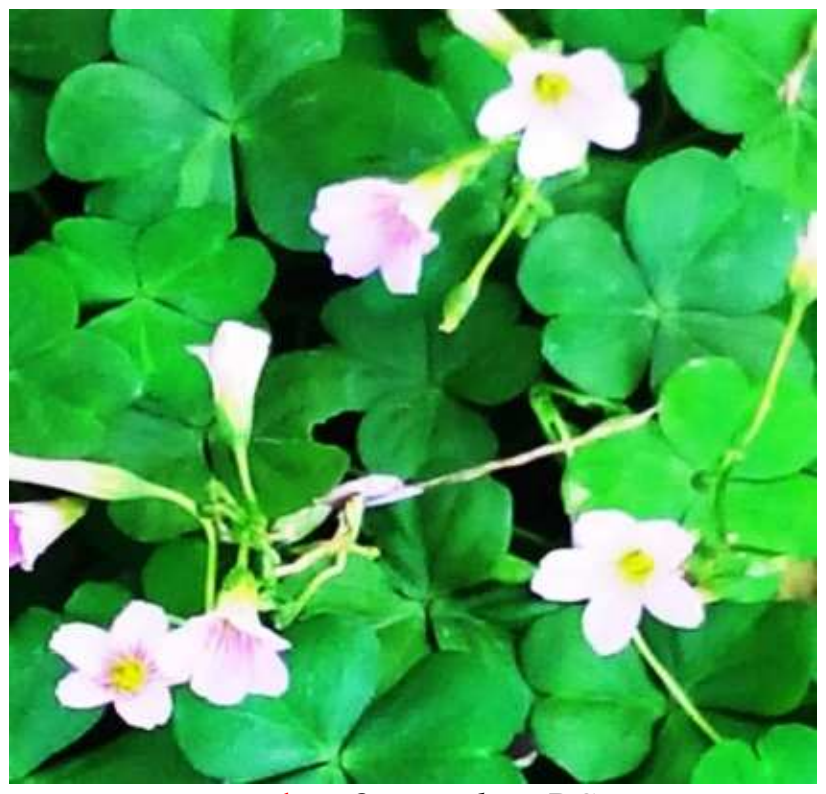

b. O. corymbosa DC. 


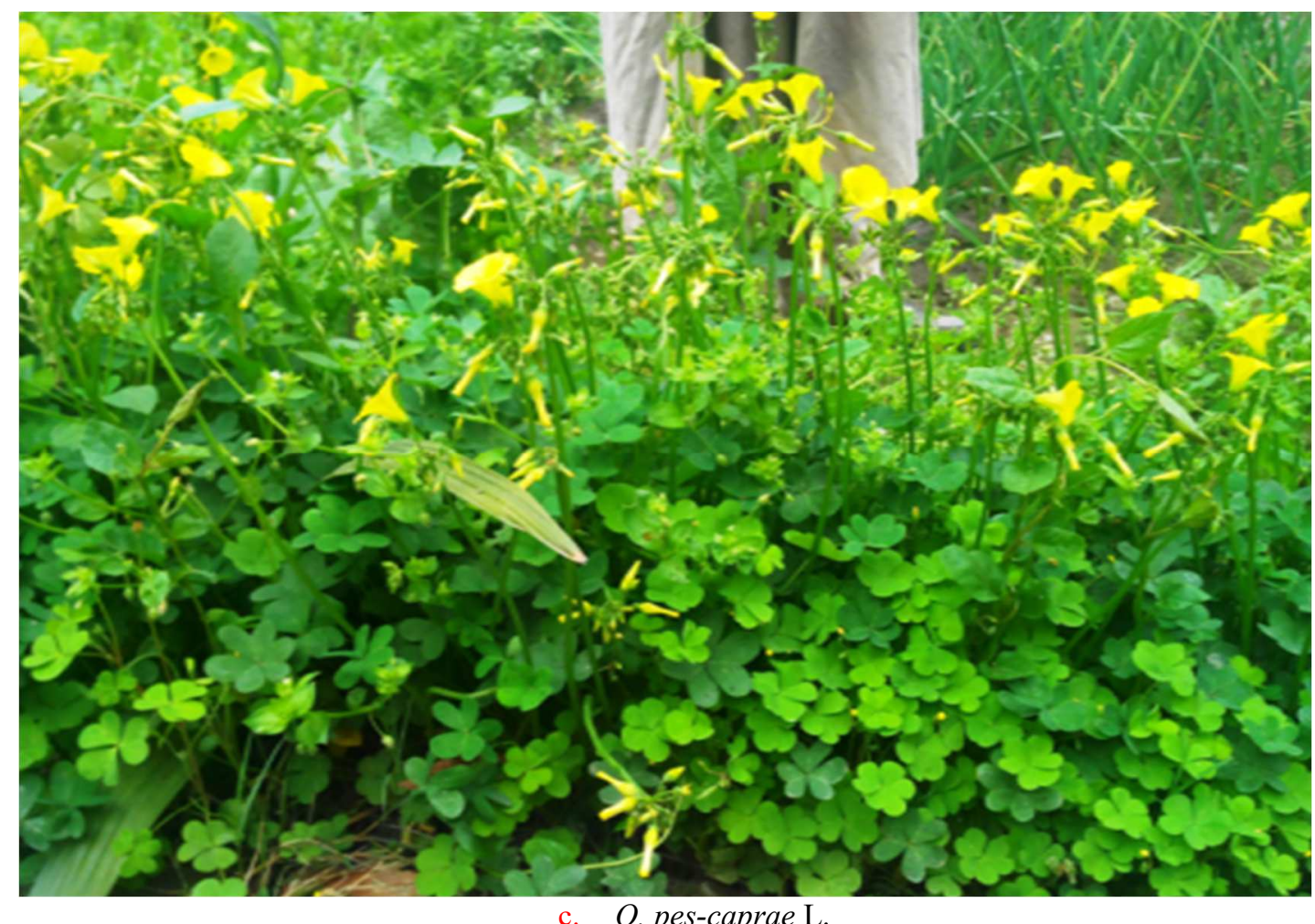

Figure 1. Three different Oxalis spp.

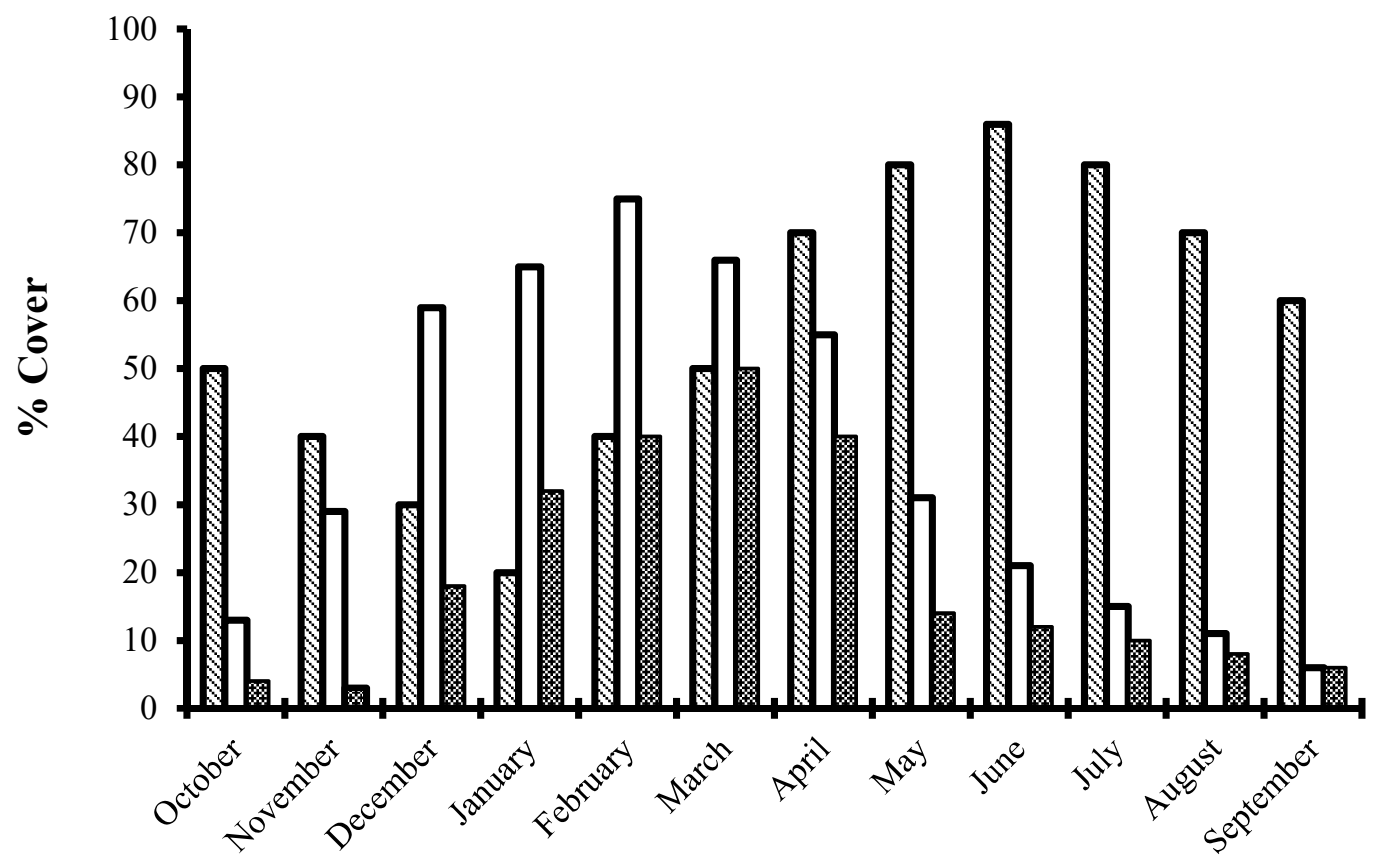

Months

$$
\text { ه Oxalis corniculata Oxalis corymbosa Oxalis pes-caprae }
$$

Figure 2. Percentage cover of Oxalis spp. 


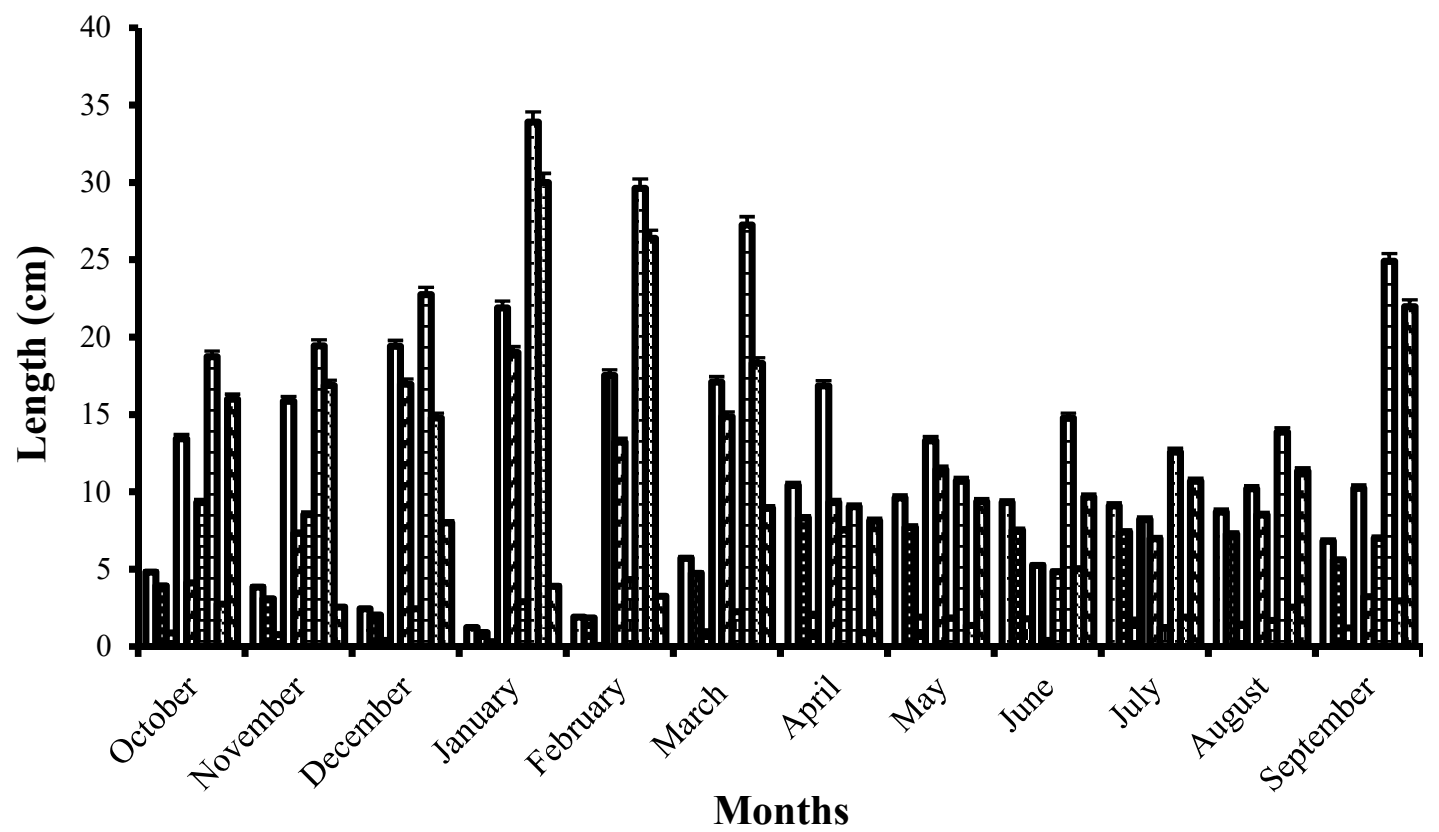

\begin{tabular}{|c|c|c|}
\hline $\begin{array}{l}\text { QO. corniculata Total Plant } \\
\text { QO. corymbosa Total Plant } \\
\mathbf{0} O . \text { pes-caprae Total Plant }\end{array}$ & $\begin{array}{l}\text {-O. corniculata Shoot } \\
\text {-O. corymbosa Shoot } \\
\mathbf{0} \text { O. pes-caprae Shoot }\end{array}$ & $\begin{array}{l}\text { DO. corniculata Root } \\
\text {-O. corymobsa Root } \\
\mathbf{Q} O \text {. pes-caprae Root }\end{array}$ \\
\hline
\end{tabular}

*Standard error, $\mathrm{p}<0.05$.

Figure 3. Length variations of Oxalis spp.

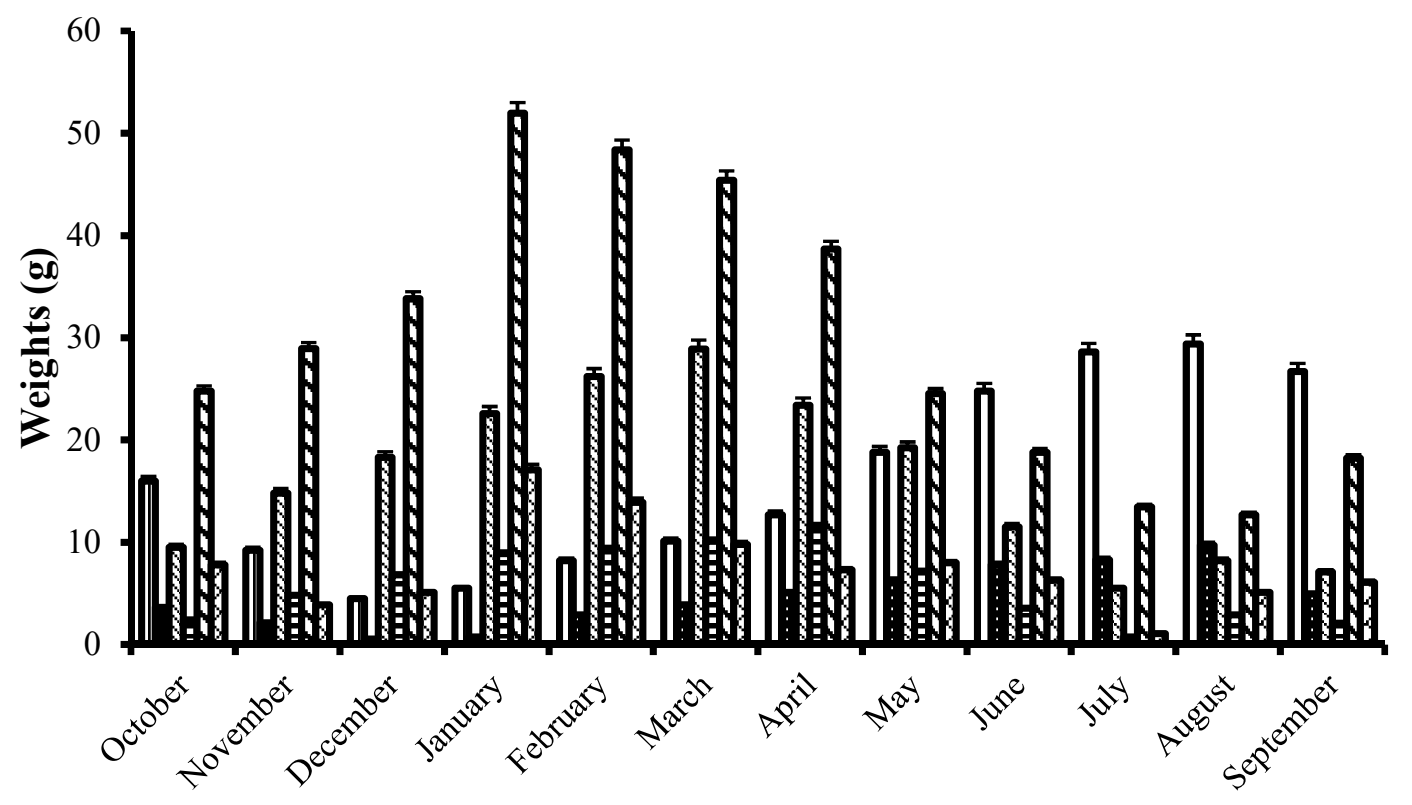

Months

\begin{tabular}{|c|c|c|}
\hline $\begin{array}{l}\text {-O. corniculata Fresh Weight } \\
\text {-O. corymbosa Dry Weight }\end{array}$ & $\begin{array}{l}\text {-O. corniculata Dry Weight } \\
\text {-O. pes-caprae Fresh Weight }\end{array}$ & $\begin{array}{l}\mathbf{v} O \text {. corymbosa Fresh Weight } \\
\text { םO. pes-caprae Dry Weight }\end{array}$ \\
\hline
\end{tabular}

${ }^{*}$ Standard error, $\mathrm{p}<0.05$.

Figure 4. Weight measurements of Oxalis spp. 


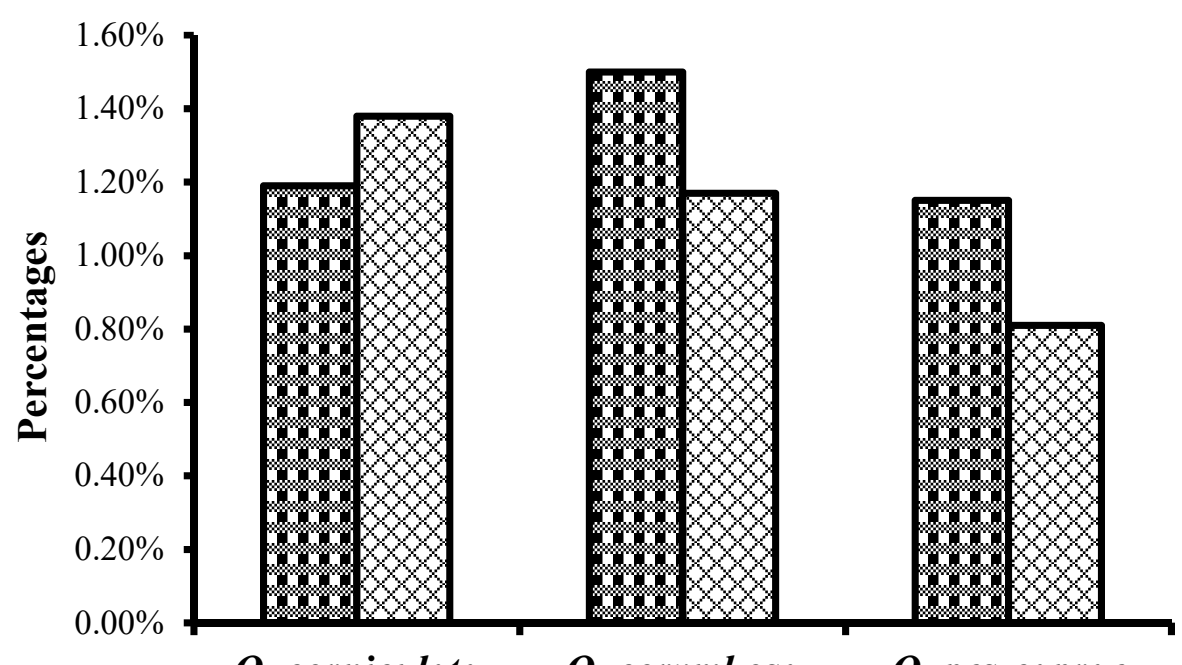
O. corniculata
O. corymbosa
O. pes-caprae

\section{\$Moisture $\mathbf{0}$ Organic Matter}

Figure 5. Soil analyses for Oxalis spp.

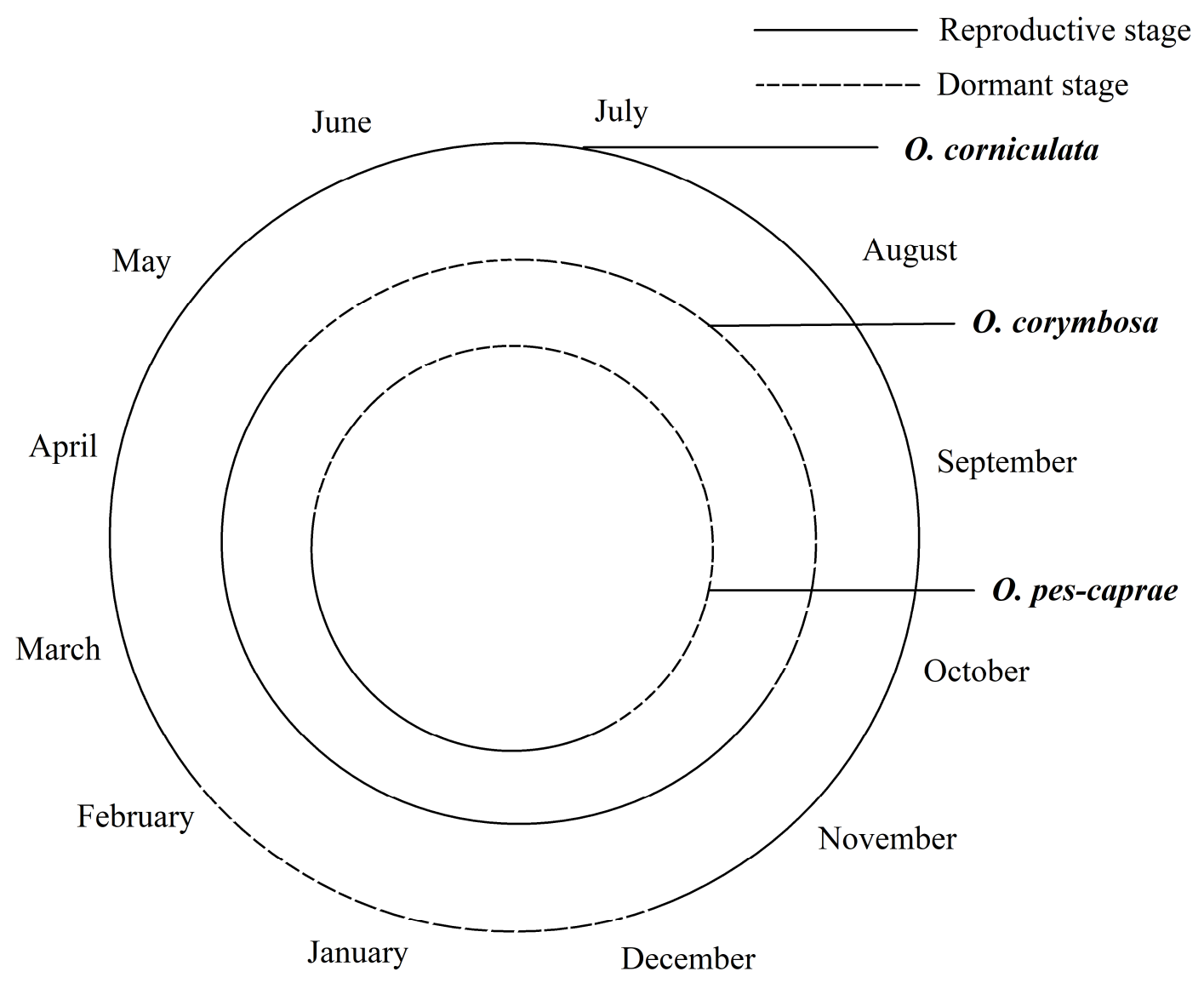

Figure 6. Life cycles of Oxalis spp. 


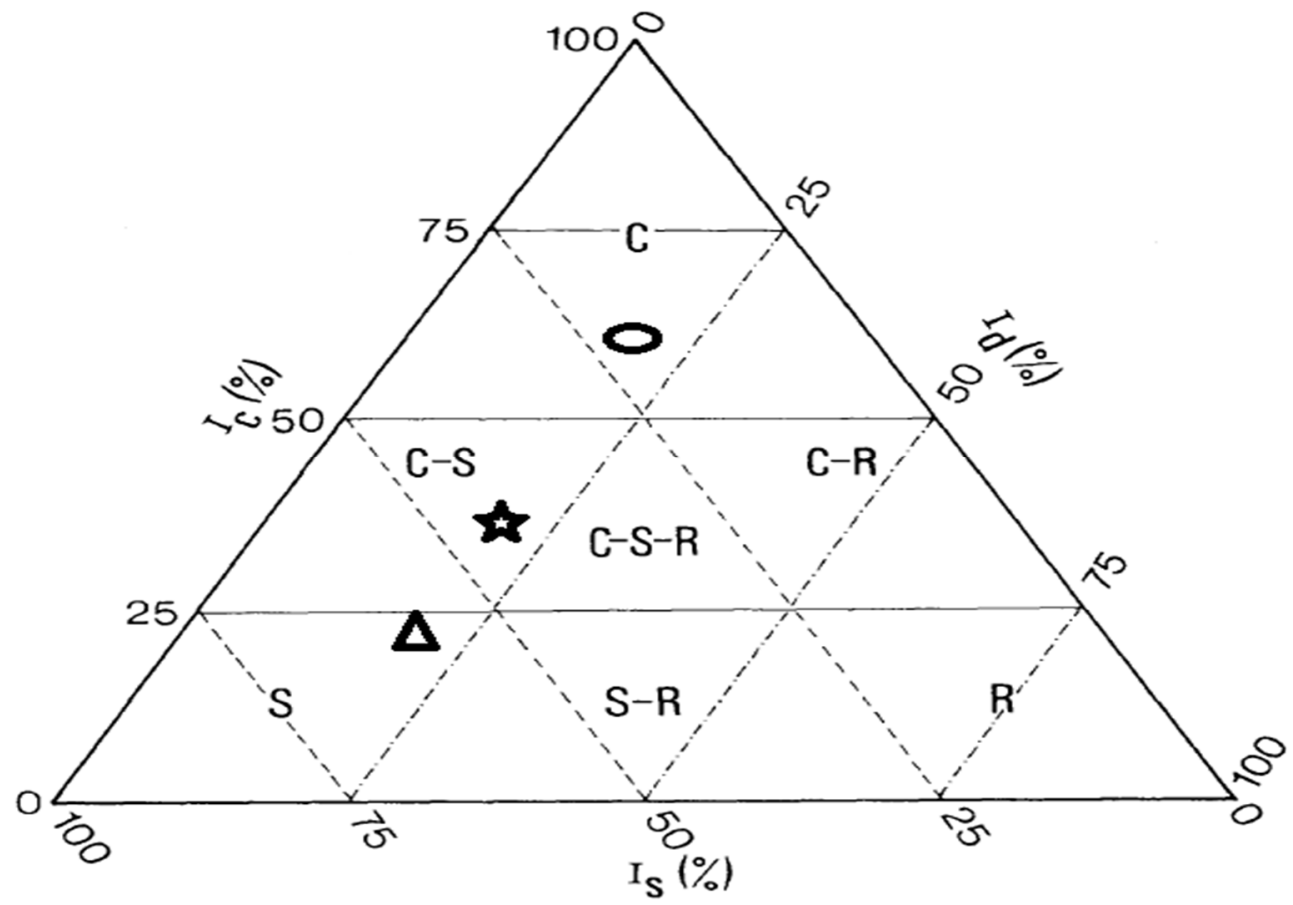

${ }^{*} I_{c}$ : Relative importance of competition (

${ }^{*} \mathrm{I}_{\mathrm{S}}$ : Relative importance of stress-tolerance (-------)

${ }^{*} \mathrm{I}_{\mathrm{d}}$ : Relative importance of disturbance (-.-.-.-.-)

${ }^{*}$ The triangle model is reproduced from Grime (1977)

Figure 7: $\quad$ Grime's triangle illustrating the location of $O$. corniculata $(\bigcirc)$, o. corymbosa $(\star)$ and $O$. pescaprae $(\Delta)$ according to their strategies

Table 1. Morphological comparison of rhizomes.

\begin{tabular}{|c|c|c|}
\hline O. corniculata & O. corymbose & O. pes-caprae \\
\hline $\begin{array}{l}\text { 1. Root stock is a slender. Tap-roots } \\
\text { are sometimes woody. }\end{array}$ & $\begin{array}{l}\text { 1. Compound bulbs are present } \\
\text { (formed by clustering of simple } \\
\text { bulbils). }\end{array}$ & $\begin{array}{l}\text { 1. Underground rhizome bearing } \\
\text { bulbils are present. }\end{array}$ \\
\hline $\begin{array}{l}\text { 2. Rooting at nodes is observed. } \\
\text { Perennating organs are observed. } \\
\text { Seed pod are } 2-3 \text { at each node. }\end{array}$ & $\begin{array}{l}\text { 2. Sessile bulbils are almost } 3-6 \mathrm{~mm} \\
\text { in length. Perennating organs are } \\
\text { present having } 30-40 \text { bulbils in a } \\
\text { compound bulb. Seeds are absent. }\end{array}$ & $\begin{array}{l}\text { 2. Bulbs are present with white and } \\
\text { fleshy contractile roots. They are } \\
\text { arising from a single bulb } \\
\text { adjacent to rhizome. Bulbs are } \\
6-8 \text { in numbers. Seeds are } \\
\text { absent. }\end{array}$ \\
\hline
\end{tabular}

Conclusion: $O$. corniculata is present abundantly as garden weed. It possesses highest percentage organic content and has tendency to compete with the disturbance. This concluded the presence of this plant as Competitive Ruderal (C-R) as it grew at less-disturbed sites. Oxalis corymbosa is present along the drains, in wastelands or areas with abundant moisture in soil. The percentage moisture content for the occurrence of this species was also highest in this species. This concluded the presence of this plant as Stress-tolerant Ruderal (S$\mathrm{R})$. O. pes-caprae is present along the margins of arable fields. It requires soil having less moisture content to grow. The less percentage organic content and incompetence to compete with the disturbance suggested this species as Stress-tolerant ruderals (S-R).

Acknowledgements: Authors are grateful to the Department of Botany and Vice Chancellor, GC University Lahore for providing research facilities and moral assistance.

\section{REFERENCES}

Askari, A.H.S. (2010). Poisonous plants of Pakistan. $1^{\text {st }}$ Ed., Oxford University Press, Lahore, Pakistan. 
Badwaik, H., M.K. Singh, D. Thakur, T.K. Giri and D.K. Tripathi (2011). The botany, chemistry, pharmacological and therapeutic application of Oxalis corniculata Linn. - a review. Int. J. Phytomed. 3(1): 01-08.

Burt, R., Natural Resources Conservation Service and U.S. Department of Agriculture (2013). Soil survey laboratory methods. $1^{\text {st }}$ Ed., Books Express Publishing, USA.

Castro, S., J. Loureiro, C. Santos, M. Ater, G. Ayensal and L. Navarro (2006). Distribution of flower morphs, ploidy level and sexual reproduction of the invasive weed Oxalis pes-caprae in the western area of the Mediterranean region. Ann. Bot. 99(3): 507-517.

Causton, D.R. and J.C. Venus (1981). The biometry of plant growth. $1^{\text {st }}$ Ed., Edward Arnold, London, UK.

Evans, G.C. (1973). The quantitative analysis of plant growth. $1^{\text {st }}$ Ed., Blackwell Scientific Publications, Oxford, UK.

Fukatsu, M., S. Horie, M. Maki and I. Dohzono (2019). Hybridization, coexistence, and possible reproductive interference between native Oxalis corniculata and alien $O$. dillenii in Japan. Plant Syst. Evol. 305 (1): 127-137.

Grime, J.P. (1977). Evidence for the existence of three primary strategies in plants and its relevance to ecological and evolutionary theory. Am. Nat. 111(1): 1169-1194.

Grime, J.P. (1979). Plant strategies and vegetation processes. $1^{\text {st }}$ Ed., John Wiley and Sons Ltd.; Chichester (UK).

Grime, J.P. (2001). Plant strategies, vegetation processes and ecosystem properties. $2^{\text {nd }}$ Ed., Wiley, Chichester, UK.

Grime, J.P., J.G. Hodgson, and R. Hunt (2007). Comparative plant ecology: a functional approach to common British species, $2^{\text {nd }}$ Ed., Castlepoint Press, Colvend, UK.

Grime, J.P. and S. Pierce (2012). The evolutionary strategies that shape ecosystems. $1^{\text {st }}$ Ed., WileyBlackwell, Chichester, UK.

Hunt, R. (2012). Basic growth analysis: Plant growth analysis for beginners. $1^{\text {st }}$ Ed., Unwin Hyman, London, UK.

Jain, A.K., P.T. Barua and M. Bashir (2010). Nutritive aspects of Oxalis corniculata L. used by tribal of central India during scarcity of food. J. Am. Sci. 6(11): 435-437.

Kashyap, S.R. (2015). Lahore district flora. $1^{\text {st }} \mathrm{Ed}$ (Reprint)., BiblioBazaar, USA.

Kathiriya, A., K. Das, E.P. Kumar and K.B. Mathai (2010). Evaluation of antitumor and antioxidant activity of Oxalis corniculata Linn. against
Ehrlich Ascites carcinoma on mice. Iran. J. Can. Prevent. 3(4): 157-165.

Kumar, A., S. Rani and S. Sagwal (2012). An absolute review on Oxalis corniculata Linn. Int. J. Res. Pharm. Biomed. Sci. 3(3): 1173-1188.

Malik, M.I., S. Mahmood, G. Yasin and N. Bashir (2012). Oxalis corniculata as a successful lawn weed: a study of morphological variation from contrasting habitats. Pakistan J. Bot. 44(1): 407-411.

Mehmood, F., A.H. Khan and Z.D. Khan (2011). Appraisal of ecological significance of Ricinus communis Linn. in the wasteland of Lahore, Pakistan. Biologia. 57 (1\&2): 97-103.

Mufti, R., Amna, M. Rafique, F. Haq, M.F.H. Munis, S. Masood, A.S. Mumtaz and H.J. Chaudhary (2015). Genetic diversity and metal resistance assessment of endophytes isolated from Oxalis corniculata. Soil Environ. 34(1): 89-99.

Nasir, Y. (1971). Fl. W. Pakistan: Oxalidaceae, In: Nasir and S.I. Ali. Ferozsons Ltd., Rawalpindi and Department of Botany, University of Karachi, Karachi, Pakistan.

Peng, Y., Y.J. Hu and X.Z. Su (2007). Research on allelopathic effects of Oxalis corymbosa - an invasive species. Acta Prata. Sinica 16(1): 90-95.

Pierce, S., G. Brusa, I. Vagge and B.E.L. Cerabolini (2013). Allocating CSR plant functional types: the use of leaf economics and size traits to classify woody and herbaceous vascular plants. Funct. Ecol. 203(1): 1-9.

Pierce, S., D. Negreiros, B.E.L. Cerabolini, J. Kattge, S. Diaz, M. Kleyer, B. Shipley, S.J. Wright, N.A. Soudzilovskaia, V.G. Onipchenko, P.M.V. Bodegom, C. Frenette-Dussault, E. Weiher, B.X. Pinho, J.H.C. Cornelissen, J.P. Grime, K. Thompson, R. Hunt, P.J. Wilson, G. Buffa, O.C. Nyakunga, P.B. Reich, M. Caccianig, F. Mangili, R.M. Ceriani, A. Luzzaro, G. Brusa, A. Siefert, N.P.U. Barbosa, F.S. Chapin, W.K. Cornwell, J. Fang, G.W. Fernandes, E. Garnier, S.L. Stradic, J. Penuelas, F.P.L. Melo, A. Slaviero, M. Tabarelli and D. Tampucci. 2017. A global method for calculating plant CSR ecological strategies applied across biomes world-wide. Funct. Ecol. 31(1): 444-457.

Sala, A., D. Verdaguer and M. Vila (2007). Sensitivity of the invasive geophyte Oxalis pes-caprae to nutrient availability and competition. Ann. Bot. 99(1): 637-645.

Shu, C.J.C. (2008). Oxalis Linnaeus sp. (1753). Flora China. 11(1): 2-6.

Stohlgren, T.J. (2007). Measuring plant diversity: lessons from the field. $1^{\text {st }}$ Ed., Oxford University Press, USA.

Steel, R.G.D., J. H. Torrie and D.A. Dickey (1996). Principles and procedures of statistics: A 
biometrical approach. $3^{\text {rd }}$ Ed., McGraw Hill, New York, USA.

Sykes, W.R., C.J. Webb and P.J. Garnock-Jones (2009). Flora of New Zealand: Naturalized Pteridophytes, Gymnosperms, Dicotyledons. Digital Ed., D.S.I.R, Botany Division, Christchurch, New Zealand.

Tilman, D. (1988). Plant strategies and the dynamics and structure of plant communities. $1^{\text {st }}$ Ed., Monographs in population biology, Princeton University Press, Princeton, NJ, USA.
Tsai, M.Y., S.H. Chen and W.Y. Kao (2010). Floral morphs, pollen viability, and ploidy level of Oxalis corymbosa DC in Taiwan. Bot. Stud. 51(1): 81-88.

Vila, M., I. Bartomeus, I. Gimeno, A. Traveset and E. Morageus (2006). Demography of the invasive geophyte Oxalis pes-caprae across a Mediterranean island. Ann. Bot. 97(1): 10551062. 